\title{
UNDERSTANDING THE BOOKING PATTERNS OF INDIAN OUTBOUND TRAVELLERS
}

\author{
Bivek DATTA* \\ Amity University Uttar Pradesh, Amity Institute of Travel and Tourism, \\ Sector-125, Noida, India, e-mail: bdatta@amity.edu
}

\begin{abstract}
Citation: Datta, B. (2019). UNDERSTANDING THE BOOKING PATTERNS OF INDIAN OUTBOUND TRAVELLERS. GeoJournal of Tourism and Geosites, 24(1), 246-251. https://doi.org/10.30892/gtg.24119-356
\end{abstract}

\begin{abstract}
The purpose of this paper is to make a sincere attempt to understand the booking patterns of the Indian outbound travellers. The Paper investigates the booking patterns of the Indian outbound travellers. Limited literatures are available on Indian outbound travellers and their buying pattern is least researched by the scholarly community. The study will try to fill the gap in the scholarly studies being undertaken and will help the policy makers to frame the policies pertaining to the buying patterns of the Indian outbound travellers which is growing by leaps and bound. This is a grey area especially from the Indian perspective as it is least researched. Primary research has been carried out on a sample worked upon through the Slovins formula. The research findings will be of keen interest to both the academia and the industry actively involved in research pertaining to the booking patterns of the outbound travellers from India. The results arising from primary research indicate that social media plays a major role in influencing the holiday plans and booking patterns of Indian outbound travellers.
\end{abstract}

Key Words: Outbound travellers, India, Booking patterns

\section{INTRODUCTION}

Tourism in India has come a long way though India was very late in capitalizing the economic importance of Tourism. Tourism worldwide has been understood as a major tool for economic development, societal upliftment, poverty alleviation and a major tool for International understanding. After 1991 there has been unprecedented economic growth understandable from the point of view of growing economic levels and burgeoning business opportunities. The sudden increase in the economic levels and disposable incomes fielded the way for the growth of outbound Tourism in India. The growth has been phenomenal in terms of outbound Tourism in India. The outbound Tourism was 1.94 million (1991) and has increased to 21.87 million (2016) with a CAGR of $10.17 \%$. The information regarding the destination which the Indian outbound travellers prefer while undertaking outbound Travel cannot be spoken in length because of the lack of the pertinent data and nonavailability of the data from the Bureau of Immigration, Government of India. Therefore

\footnotetext{
* Corresponding author
} 
there is more reliance on the publication data of UNWTO. In 2015 the Indian outbound travellers travelled to Saudi Arabia, Bahrain, USA, Kuwait and Thailand. Three of the nations belong to the Gulf Cooperation Council (GCC Countries). As far as the departure ports in the last decade is concerned it is majorly concentrated across Mumbai, New Delhi, Kochi, Chennai, Hyderabad, Bengaluru, Calicut, Thiruvananthapuram, Kolkata, Ahmedabad.

Table 1. Number of Indian National's Departure from India (Source: Bureau of Immigration, India)

\begin{tabular}{|c|c|c|}
\hline Year & Outbound Tourism from India & Annual Percentage Change \\
\hline 1991 & 1.94 million & $-14.8 \%$ \\
\hline 1995 & 3.056 million & $11.8 \%$ \\
\hline 2000 & 4.41 million & $3.4 \%$ \\
\hline 2005 & 7.18 million & $15.6 \%$ \\
\hline 2010 & 12.98 million & $17.4 \%$ \\
\hline 2015 & 20.37 million & $11.1 \%$ \\
\hline 2016 & 21.87 million & $7.3 \%$ \\
\hline 2017 & 23.94 million & $9.5 \%$ \\
\hline
\end{tabular}

It is also inferred that the share of the top ten ports in terms of India's outbound in the last decade has decreased from 91.6\% (2009) to 88.2\% (2016). During 2016 the top three departure airports were Mumbai (21.45\%), New Delhi (20.46\%), Kochi (10.02\%) and accounted for almost $52 \%$ of the total departures. As far as means of transport used by India's outbound travellers is concerned the most preferred is by Air (98.5\%), Land (1.3\%), Sea (0.2\%). Outbound tourism is on the rise from the Indian perspective .India will account for 50 million outbound tourists by 2020 (UNWTO). India' outbound market is expected to grow close to 45 billion USD by 2022 and this is a fantastic news for majority of the Asian counterparts as Indians have a knack of visiting majority of these destinations in proximity. The destinations preferred by the India's outbound community are short haul and budget destinations. Long distance destinations preferred by the Indian outbound travellers are destinations, USA, Australia and New Zealand to name a few.

In the past India was struggling to establish its status at the global arena and the era of 1991 was a turning point in India due to the liberalization, privatization and globalization initiatives taken by the Indian government. The outbound travel during that period was very minimal accounting to only 1.94 million (1991, BOI) and has swelled to 21.87 million (2016, BOI) thanks to the growing middle class in India which has a visible growth in terms of the disposable income. After discussing in length and breadth of the scenario of the Indian outbound Tourism and its growth in numerical sense and the departure gateways it is imperative now to understand the psyche of the Indian outbound Tourist which is growing by leaps and bounds. The study is an earnest attempt to link and fill the gap between the growing aspect of the Indian outbound Tourism and the booking patterns and the holiday plans of the burgeoning Indian outbound traveller. Since the research area is very vast, a sincere attempt has been made to investigate whether the social media influence the holiday plans of Indian outbound travelers.

\section{LITERATURE REVIEW}

India's outbound Tourism research has caught the eye of the scholarly community because of the growing middle class. In spite of the global melt down India's outbound numbers are increasing and India is emerging as a major Tourism force of the World. The Indian outbound Travel should increase from around 15 Million to 50 Million by 2020 (Tourism Australia). India is the second fastest growing outbound market after China. In terms of numbers Indian outbound tourist spending is the highest in the United States of America as it is the most preferred destination for the Indians as they spend $30 \%$ of the total 
spending as far as outbound Travel Spending is concerned. This desire of the Indians to travel is encouraged by more than 60 international nations which established tourism promotion offices in India. TTCI biennial Report published by the World Economic Forum takes into account the policies established by countries to develop their travel and tourism sector. According to its 2017 Travel and Tourism competitiveness index, India ranked 40 whereas India's rank in terms of TTCI in 2015 was 52. Tourism Industry will be majorly driven by the growing middle class. Consequently the prospective of Indian tourists is huge. The huge economic boom and further economic development will motivate the Indians to travel in huge numbers around the world. As a result a rising number of countries will compete for a larger share of the huge Indian market by reducing the prices. India is now accepted as a major emerging outbound tourism worldwide market (WTTC, 2006). A large proportion of Indians are able to afford to take foreign trips i.e. 12million in 2009 (Lander, 2010).

Selecting a destination is often a intricate and tough decision-making process as people have dissimilar destination inclinations and expectations whereas they have to pay in advance for it without a clue whether it will be a pleasant trip or not (Zhang, 2009). Approximately 9 million foreign trips were undertaken by Indians last year and this number is expected to grow to around 50 million by the year 2020 (Tourism Australia, 2012).

Review of literature indicates that in the framework of e-commerce there are many functional service qualities which are valued by customers during online purchase such as fast connectivity, security issues and user friendly network (Dhar \& Wertenbroch, 2000). Income and age group impacts the online purchase attitude of travellers (Datta et al., 2018a). Business travellers value confidentiality, security and product quality the most while choosing the Online Travel Portal to book their trip (Datta et al., 2018b). The growing role of social media in tourism has been increasingly an emerging research topic. Social media plays a significant role in many aspects of tourism, especially in information search and decision-making behaviour, tourism promotion and in focusing on best practices for interacting with consumers (Zen et al., 2014). The perceived quality of a product or service may influence the post-consumption behaviour of tourists (e.g. Chen \& Tsai, 2007; Chi \& $\mathrm{Qu}$, 2008; Zhang et al., 2014). Online searches can provide tourists with considerable information regarding destinations, more so than what can be obtained in travel brochures (Klahn, 2015). Tourist expectation has been defined as a preconceived perception of travel outcome (Wang et al., 2016). In the academic discipline of travel and tourism, past research findings have fixated attention on the socio-psychological facets of the use of social media.

Not unexpectedly, travel related virtual communities attracted the attention of tourism researchers (Kim et al., 2004; Wang \& Fesenmaier, 2003; Wang et al., 2002). Search engines can be seen as an instruments of information in the cyber space where businesses in the tourism industry strive for attention of online travellers, because the representation of the domain is largely based upon the ranking and position of search results and will be influenced by dependent factors such as the presence of online advertisements (Kim \& Fesenmaier, 2008; Pan et al., 2007a; Spink \& Jansen, 2004). Consumers tend to buy familiar and well known products as they feel more confident with what they are actually buying (Chi et al., 2009). The average Indian traveller spends $\$ 1,200$ per trip as compared to Americans who spend about \$700, and British spend \$500. Indian outbound travellers come from Tier 1 cities such as New Delhi, Mumbai, Chennai and Bangalore, but lately smaller cities like Jaipur, Ahmedabad and Amritsar are emerging as important source markets for outbound travel as well.

\section{METHODOLOGY}

The researcher has utilized the quantitative approach for the study undertaken. The study instrument was a questionnaire with questions pertaining to booking patterns of 
the Indian outbound travellers. The primary information is thus collected from the structured questionnaire designed for Indian outbound travellers. Four international airports were chosen for the survey i.e. Mumbai in the west, New Delhi in the North, Kolkata in the east and Chennai in the South. These four cities were chosen because they are the four metros of India and accounted for $56 \%$ of the Indian outbound departures (BOI, 2017). A questionnaire was designed for outbound Indian travellers. The first section contains the demography of the respondents. Section two uses items based on five point Likert Scale, ranging from Never (1) to Always (5). In total 400 valid questionnaires were collected. The respondent could select more than one option pertaining to information about the travel booking by Indian outbound Traveller. Questions were asked pertaining to frequency of outbound trips, facilities, service providers, information about the destination before considering it for outbound travel booking. Data was collected from the departure lounge of all the above mentioned four international airports. No gender bias was examined in the sample during the primary survey. 56\% are male and $44 \%$ are females. All the variables mentioned in the questionnaire are inputted in the variable view. The Data was analyzed through the SPSS Software and the results are discussed. Slovins formula was used for sample size determination. The study will help us to understand whether the social media plays a role in influencing the decision making and deciding the holiday plans of the Indian outbound Traveller. The below mentioned research question will be answered after testing the hypothesis framed.

\section{SAMPLE SIZE DETERMINATION}

Determination of the Sample Size was done by using the Slovins (1960) formula which is as follows:

$$
\begin{aligned}
& \mathrm{n}=\mathrm{N} / 1+\mathrm{N} \mathrm{e}^{2} \\
& \text { Where } \mathrm{n}=\text { Sample Size, } \mathrm{N}=\text { Population Size, e=Margin of Error/Error margin } \\
& \text { For the year } 2017 \text { the outbound Tourism of India=23940000 } \\
& \mathrm{n}=\mathrm{N} / 1+\mathrm{N} \mathrm{e}^{2} \\
& 23940000 / 1+23940000 .(0.05)^{2} \\
& =23940000 / 1+59850 \\
& =23940000 / 59851 \\
& =399.99 \\
& =400
\end{aligned}
$$$$
\text { For the year } 2017 \text { the outbound Tourism of India }=23940000
$$

The researcher managed to get 400 Questionnaires filled from the Indian outbound travellers from North, West, East, and South India.

\section{RESEARCH QUESTION} travellers?

RQ1: Do the Social media influence the holiday plans of Indian outbound

H1: The higher the perceived level of social media influence, the more likely changes would be made in holiday plans by Indian outbound travellers

\section{RESULTS AND DISCUSSION}

In today's context the freedom of choice for Indian outbound travellers is more apparent than ever before. An empirical study was carried out to understand the booking patterns of Indian outbound travellers who are growing by leaps and bounds. Primary research was carried out to understand to understand the booking patterns of outbound travellers from India and to understand the impact of social media in influencing the booking plans of the outbound travellers of India. In the era of technology an earnest attempt has been made in understanding its impact on the booking patterns of the 
travellers of India. The study was conducted in North, South, East and West India. Four international airports were chosen across the four geographical coordinates of India i.e. New Delhi to the north, Mumbai to the west, Kolkata to the east and Chennai to the south. These four cities were chosen as these are the four metropolitans of India. A sample of 400 respondents was selected and studied using convenience sampling technique. The primary data is procured using structured questionnaire with five point Likert scale.

Table 2 reveals that the respondents are getting information through Social Media (43.0 percent) followed by Internet Search (40.0 percent). The survey also reveals that social media is the most effective tool that impact the holiday plans of Indian outbound travellers. The respondents have the flexibility in selecting more than one answer pertaining to information about the travel booking by Indian outbound traveller.

Table 2. Information about the travel booking by Indian outbound Traveller (Source: Primary Research)

\begin{tabular}{|c|c|c|c|}
\hline Sr. No. & Attributes & No's & \% \\
\hline 1 & Social Media & $\mathbf{1 7 2}$ & $43 \%$ \\
\hline 2 & Friends and acquaintances & 04 & $\mathbf{1 \%}$ \\
\hline 3 & Advertisements & 64 & $16 \%$ \\
\hline 4 & Employer & 0 & $0 \%$ \\
\hline 5 & Internet Search & $\mathbf{1 6 0}$ & $40 \%$ \\
\hline 6 & Any others(Specify) & $\mathbf{0}$ & $\mathbf{0} \%$ \\
\hline \multicolumn{2}{r}{} & $\mathbf{4 0 0}$ & $\mathbf{1 0 0 \%}$ \\
\hline
\end{tabular}

\section{HYPOTHESIS TESTING}

Table 3 below reflects that the largest positive gap came from Social Media, Internet Search and Advertisement while friends and acquaintances, employers and others had a negative gap between the higher level of importance and lower levels of satisfaction. Therefore the higher the perceived level of social media influence, the more likely changes would be made in holiday plans by Indian outbound travellers.

Social media plays a major role in influencing the holiday plans and booking patterns of Indian outbound travellers.

Table 3. Paired t-test on outbound Indian travellers attributes and services (Source: Primary Data, Wixon and Todd Model, 2005)

\begin{tabular}{|l|c|c|c|c|c|}
\hline \multicolumn{1}{|c|}{ Attributes } & $\begin{array}{c}\text { Expectations } \\
\text { (pre-booking) }\end{array}$ & $\begin{array}{c}\text { Experiences } \\
\text { (post-booking) }\end{array}$ & Gap & t-value & p value \\
\hline Social Media & $\mathbf{3 . 3 8 2}$ & $\mathbf{3 . 8 2 3}$ & $\mathbf{0 . 4 4 1}$ & $\mathbf{5 . 9 3 2}$ & $\mathbf{0 . 0 0 0}$ \\
\hline Friends and acquaintances & $\mathbf{3 . 1 2 3}$ & $\mathbf{3 . 0 7 8}$ & $-\mathbf{0 . 0 4 5}$ & $-\mathbf{0 . 8 6 5}$ & $\mathbf{0 . 3 8 8}$ \\
\hline Advertisements & $\mathbf{3 . 6 8} 7$ & $\mathbf{3 . 7 8 8}$ & $\mathbf{0 . 1 0 1}$ & $\mathbf{0 . 5 6 0}$ & $\mathbf{0 . 0 0 0}$ \\
\hline Employers & $\mathbf{3 . 1 1 8}$ & $\mathbf{3 . 1 1 8}$ & $\mathbf{0 . 0 0 0}$ & $\mathbf{- 3 . 0 8 9}$ & $\mathbf{0 . 1 1 5}$ \\
\hline Internet Search & $\mathbf{3 . 0 3 2}$ & $\mathbf{3 . 4 3 1}$ & $\mathbf{0 . 3 9 9}$ & $\mathbf{5 . 1 3 2}$ & $\mathbf{0 . 0 0 0}$ \\
\hline Any others(Specify) & $\mathbf{3 . 8 1 1 8}$ & $\mathbf{3 . 8 1 1 8}$ & $\mathbf{0 . 0 0 0}$ & $\mathbf{- 0 . 7 7 6}$ & $\mathbf{0 . 4 1 6}$ \\
\hline
\end{tabular}

\section{CONCLUSION}

It is quite evident from the literature review that this is the era of digitalization as it saves time, money and most importantly the waiting period. The World Wide Web has changed the business environment and competitive behavior in many industries because consumers now have more access to market information. The speed at which the Internet has revolutionized information availability and information sharing has taken managers by surprise. While many firms have failed in their effort to implement sound Internet strategies in an environment where consumers are better informed, other firms with creative strategies have succeeded. Since the Indian outbound travellers are a growing niche and contributing immensely in economic terms so their preferences and needs should be properly addressed and carefully examined by the service providers. Indian 
outbound travellers value time and convenience as they are always on the move. They also require secure and safe payment gateway, varied options and user friendly services in the service provider. Indian outbound Tourism segment is growing at a rapid pace and needs a thorough attention by the scholarly community. Indian outbound data indicate that India will account for 50 million outbound tourists by 2020 (UNWTO). India's outbound market is expected to grow close to 45 billion USD by 2022. To understand the psyche of the Indian outbound Tourist the service providers have to be ready in all aspects as this is a major revenue generating segment and catering to this segment will reap fruits for them. The testing of hypothesis specifies that social media is the most effective tool that impact the holiday plans of Indian outbound travellers.

\section{REFERENCES}

Chen, C.F., \& Tsai, D. (2007). How destination image and evaluative factors affect behavioral intentions? Tourism management, vol. 28, no. 4, pp. 1115-1122.

Chi, C.G.Q., \& Qu, H. (2008), Examining the structural relationships of destination image, tourist satisfaction and destination loyalty: An integrated approach, Tourism management, vol. 29, no. 4, pp. 624-636.

Datta, B., Sajnani, M., \& Thomas, J. (2018a). Travellers Attitude Towards Online Purchase Of Travel Products: An Empirical Study Of Online Travel Portals. GeoJournal Of Tourism And Geosites. 21(1), 133-142.

Datta, B., Sajnani, M., \& Thomas, J. (2018b). The Decision Making Of Business Travellers In Selecting Online Travel Portals For Travel Booking: An Empirical Study Of Delhi National Capital Region, India. GeoJournal Of Tourism And Geosites. 22(2), 339-346.

Dhar, R., \& Wertenbroch, K. (2000). Consumer Choice between Hedonic and Utilitarian Goods, Journal of Marketing Research, vol. 37, no. 1, p 60-71.

Kim, H., \& Fesenmaier, D.R. (2008). Persuasive design of destination Websites: an analysis of first impression. Journal of Travel Research, 47(1), pp.3-13.

Kim, W. G., Lee, C., \& Hiemstra, S. J. (2004). Effects of an online virtual community on customer loyalty and travel product purchases. Tourism Management, 25(3), 343-355.

Klahn, K. (2015). Should you use a travel agent or book online? [online]. Available:http://www.cheatsheet.com /life/should-you-use-a-travel-agent.html/?a=viewall. [Accessed: 6October 2015]

Lander, S. (2010) Switzerland to woo India with Bollywood film locations tourism campaign. Travel Mail. Retrieved from http://www.dailymail.co.uk/travel/article-1255400/Switzerlandwoo-India-Bollywoodfilm-locations-tourism-campaign.html

Pan, B., Hembrooke, H., Joachims, T., Lorigo, L., Gay, G., \& Granka, L. (2007). In Google We Trust: Users' Decisions on Rank, Position, and Relevance. Journal of Computer-Mediated Communication, 12(3), 801-823.

Spink, A., \& Jansen, B. J. (2004). Web Search: Public Searching of the Web. New York: Kluwer

Wang, Y., \& Fesenmaier, D.R. (2003). Assessing motivation of contribution in online communities: an empirical investigation of an online travel community. Electronic Markets, 13(1), 33-45.

Wang, Y., Yu, Q., \& Fesenmaier, D.R. (2002). Defining the virtual tourist community: implications for tourism marketing. Tourism Management, 23(4), 407-417.

Wang, C., Qu, H., \& Hsu, M.K. (2016). Toward an integrated model of tourist expectation formation and gender difference, Tourism Management, vol. 54, pp. 58-71.

Benxiang, Z., \& Genitsen, R. (2014) What Do We Know About Social Media in Tourism? A Review, Australia Tourism Management Perspective, Charles Darwin University, Australia, Research gate

Zhang, W. (2009). The motivations, constraints and decision-making of Beijing outbound tourists. Unpublished doctoral thesis. University of Waikato, Hamilton, New Zealand.

Zhang, H., Fu, X., Cai, L., A., \& Lu, L., (2014). Destination image and tourist loyalty: A meta-analysis, Tourism Management, vol. 40, pp. 213-223.

*** http://boi.gov.in

*** http://www.indiatourismreview.com/features/tourism-boards-report-increasedarrivals-

**** India-2014-upbeat-about-2015/15322

*** http://www.indiatourismreview.com/features/dissecting-indian-outboundtraveler/13805, June 2013

*** http://www.indiary.org/en/news/Indian-outbound-Tourism-2-83-50

*** http://www.internetworldstats.com/stats.htm

*** The World Travel and Tourism Council (2006) [online]. Available at: <http://www.wttc.orgiengt Tourism News /Press Releases/Press_Releases 2006/WTTCJeportjor_China_and_SARS/index.php > [Accessed 9 April 2010].

Submitted:

10.12.2018
Revised:

11.03.2019
Accepted and published online 13.03 .2019 